\title{
EXPLORING SERVICE LEARNING FROM THE PERSPECTIVE OF EARLY CHILDHOOD PRE-SERVICE TEACHER EDUCATION
}

\author{
Chih-Sheng CHEN \\ Assistant Professor, Department of Child Care and Education \\ Southern Taiwan University of Science and Technology, Taiwan (R.O.C) \\ ORCID: https://orcid.org/0000-0002-7447-4204 \\ cchen05@stust.edu.tw \\ Wei GU \\ Associate Professor, College of Education and Community Innovation \\ Grand Valley State University, United States \\ ORCID: https://orcid.org/0000-0003-2016-7230 \\ guw@gvsu.edu
}

Received: November 05, $2021 \quad$ Accepted: February 01, $2022 \quad$ Published: June 30, 2022

\begin{abstract}
Suggested Citation:
Chen, C. S., \& Gu, W. (2022). Exploring service learning from the perspective of early childhood pre-service teacher education. International Online Journal of Primary Education (IOJPE), 11(1), 20-32. https://doi.org/10.55020/iojpe.1076790
\end{abstract}

(c) (i)

\begin{abstract}
Service learning has been stressed as an effective pedagogical approach to enhance students' professional skills and citizenship for future development. However, service-learning research concerning early childhood pre-service teacher education has been rarely done. This study explored how undergraduate students in an early childhood pre-service teacher education program experienced in seven different service learning activities and discussed the meanings of their experiences from the perspective of early childhood pre-service teacher education. Participants in the study were 99 undergraduate students of early childcare and education. Their speech reflections, SL (Service learning) reports and verbal presentations during the course and service learning were analyzed qualitatively. The study revealed participants experienced emotion processes. In addition, participants learned professional skills and formed their teacher traits. How to balance the student choice and the goals of the course from SL activity needs to be taken into account.
\end{abstract}

Keywords: Service-learning, early childcare and education, pre-service teacher.

\section{INTRODUCTION}

Service learning(SL), integrating academic learning and community service to increase students' learning experiences, has been advocated as a teaching and learning method (Jones, 2017; Leon et al., 2017; Lovat \& Clement, 2016; Pratt \& Danyluk, 2017; Tokke, 2017). Studies show SL plays a positive and meaningful role for students to connect academic learning with the real world (Bach, 2016; Kaye, 2010; Myers, 2016; Wilkinson et al., 2012). Furthermore, Research found SL helps students have better attitudes, enhanced communication skills and problem solving skills. Also, students can learn the importance of leadership and collaboration, be aware of citizenship, or prepare career development furtherly from SL (Anderson et al., 2019; Dean, 2000; Edmond \& Driskill, 2019; Matheson \& Petersen, 2020; Pascualy Cabo et al., 2017; Popovich \& Brooks-Hurst, 2019; Rodríguez-Nogueiraa et al., 2020; Vogelgesang \& Astin, 2000). However, although what learning outcomes of SL occur has been studied a lot, "How" SL does is less explored in research (Gardner, 2021).

For college education, SL has been applied to college students, especially in academic areas of business, engineering, language learning, and nursing (e.g., Chen, et al., 2018; Dent, et al., 2018; Furness \& Paulson, 2018; Liang, et al., 2019). However, SL research in early childhood pre-service teacher education is rare although studies concerning SL has been extensively done in the above areas (Jones, 2017; Pertersen \& Petker, 2017). For early childhood education, teacher quality is critically important for educating young children, and SL is considered as a better teaching and learning method to increase the quality (Jones, 2017). Especially, what should be done or how to do to increase teacher quality of 
early childhood education through SL has been rarely explored. In the study, as a researcher and course instructor in the academic area of early child care and education for decades, the first researcher who used SL as pedagogy for the first time tried to examine whether or not SL was a pedagogy to increase teacher quality. In addition, the second researcher as a teacher educator for decades was going to examine results from the views of teacher education in order to increase the quality of the study. Hence, this study revealed what university students of early child care and education described their experiences from their SL activities and compared the differences among their SL activities from the perspective of early childhood pre-service teacher education.

\section{Literature Review}

\section{Review of SL}

SL is defined as pedagogy to increase students' personal growth and civic responsibility through connecting students' academic learning with meaningful community service (Jones, 2017). Scholars (e.g., Chen, et al., 2018; Jacoby, 1996; Strait \& Sauer, 2004) usually views SL as an experiential learning paradigm. Flecky (2011) claimed theoretical and pedagogical approaches of SL are needed because SL is not only simply an assignment to a course, but also challenges the educator, learner, and community partners in connecting each other. Hence, in order to integrate SL into teaching, theoretical and pedagogical approaches supporting SL were explored.

From literature research, it was found that Kolb (1984) proposed a four-stage experiential cycle model involving concrete experience, reflective observation, abstract conceptualization, and active experimentation for SL rooted in philosophy of John Dewey and theory of Kurt Lewin. The cycle started with concrete experience, and learners were assigned a task to learn through active involvement at the stage. Next, at the reflective observation stage, what has been done and experienced was reviewed by learners on a personal basis and with teacher's assistance. At the third stage of the cycle, abstract conceptualization, learners formed new ideas or modified existing ideas based on reflective observation. Lastly, learners put their new/modified ideas into practice. Giles and Eyler (1994) provided nine areas (i.e., the continuity of experience, the principle of interaction, inquiry, reflective activity, truly educative projects, concrete and abstract knowledge, the great community, citizenship, and democracy) for theory development and testing based on John Dewey's educational and social philosophy (Dewey, 1990; 1916; $1933 ; 1938 ; 1946 a ; 1946 b)$. For more theoretical and pedagogical approaches of SL, Flecky (2011) stated that SL is also related with critical theory (Freire, 1973; Shor, 1987), feminist pedagogy (Weiler, 1991), pedagogy of engagement (Lowery et al., 2006), the transformational model (Kiely, 2005), and Schön's (1987) reflection in action of students and active coaching by the educator. For early childhood education, Jones (2017) stated SL theory should include Contact Theory (CT) invoked by Erickson and Santmire (2001) and Vygotskian Theory (Vygotsky, 1978). Therefore, the above theories or criteria were taken into account in the study.

\section{Teacher Quality of Early Childhood Education}

Regarding teacher quality, Kennedy (2006) stated that teacher quality was related to right combination of personality, values, knowledge and skills, and the condition of classroom. Goldstein and Lake (2000) argued the development of care was viewed as a vital concern of teacher education and the development of conceptions of caring by pre-service teachers should be enhanced. According to a public opinion poll on teacher quality (Hart \& Teeter, 2002), designing inspiring learning activities, teacher's enthusiasm and caring attitude were more concerned than a thorough understanding of knowledge content by the public for teacher quality. Also, Cochran-Smith (2003) claimed that teacher quality might have different definitions because of the diverse purposes of schooling in a democratic society.

For early childhood education, teacher quality is critically important and SL is advocated as a better way to enhance teacher quality of early childhood education (Jones, 2017; Patterson et al., 2017). Kaye (2010) stated pre-service teachers could enhance their critical thinking, problem-solving skills, leadership, community engagement, and cooperation for their future roles through SL. The United Nations Educational, Scientific and Cultural Organization (UNESCO, 2006) stressed the initial training and 
preparation of teachers were the keys for quality education which leads to good learning outcomes. Therefore, what university students learn from SL activities and how the SL activities related to teacher quality were the objectives that the study would like to explore.

\section{Research Questions}

The research objectives are to understand how SL is applied to the university students of early child care and education and to explore how it works on the university students concerning teacher education. Therefore, the research questions were:

Research Question 1: What were the descriptions of the university students in the study to their SL?

Research Question 2: What were the general and different learning outcomes among their SL?

\section{METHOD}

\section{Description of the SL Course Design}

The SL course was designed by following the above literature. In addition, as the literature also mentioned, SL not only challenges learners, but also educators and community partners. Especially, the educator executing a SL project needs to play multiple roles, such as a service-learning plan organizer, an executor, and a coach/counselor. Furthermore, the researchers argue the actual teaching environment the educator/researcher faces should be also taken into account. Therefore, the course in the study was designed also based on the following three conditions:

1. The objective of the department of early child care and education in the study. Its objective is to equip university students with warm and loving personal traits, with professional care and education knowledge, and with innovative teaching and caring practical skills.

2. Volunteer Service Act (2001/2020). Although SL should not be the same as volunteering, learning and service should be equal and meaningfully connected. In order to improve the quality of SL and ensure the rights of the served persons, according to article 9 of the Act (2001/2020), university students in the study needed to have basic training and special training courses. The courses of the basic training included the connotative meaning of volunteer service, volunteer ethics, the trend of volunteer service, self-understanding and self-affirmation, being a happy volunteer, and the laws and regulations of volunteer service; the courses of the special training, determined by the regulating departments (i.e., the department of early child care and education in the study), consisted of introduction of social welfare, introduction of community partner, the content and practice of volunteer service, social resources for volunteer service, and comprehensive discussion and brainstorming methodology for volunteer service. Therefore, the volunteer training courses were integrated into the course framework of the study and an eight-hour SL task was assigned.

3. Student Choice/Voice. As research results provided by Steinke et al. (2002), it indicated that student choice/voice will be one of predicators for successful SL. Hence, the SL task of the course in the study was discussed and decided by the students after discussing with the first researcher. What SL tasks the university students in the study chose were holding game activities for special children with special needs, cleaning the university neighborhood community, assisting an annual ceremony for special children/adults, helping fundraising activity, cleaning classrooms for an affiliated preschool of university, serving home community, or running a primary school weekend camp.

In short, the service-learning course in the study was a two credit required course designed for university students of the department of early child care and education. The course schedule consists of 12 basic and 12 special volunteer training hours, 8 hours for service-learning task, and 4 hours for service experience sharing presentation. The service-learning task was discussed and decided by students and the course instructor, following the objective of the department, the Volunteer Service Act (2001/2020) and the regulations of community/ university students served. 


\section{Participants}

Participants in the study were 99 university students of department of early child care and education who took the course. Based on the four stages of SL (i.e., Preparation, Service, Reflection, and Celebration) proposed by Fertman et al. (1996), commonly executed in Taiwan, the participants needed to do an eight-hour SL activity after 12 basic and 12 special volunteer training hours. Then, they wrote their reflection and shared/celebrated their SL experiences. In addition, student choice advocated by Steinke et al. (2002) was adopted in the study. Participants were grouped according to their interests and choices. They chose the SL activities they wanted to do. For SL tasks of the study among the participants, 38 participants chose to hold game activities for children with special needs arranged by the researcher; 29 participants chose community cleanup activities assigned by university student affairs practitioners; 11 participants assisted an annual ceremony for special children/adults of an institution for Intellectual and Developmental Disability; 9 participants helped a foundation for elders to collect receipts for the Taiwan receipt lottery on the street, known as a kind of fundraising activity in Taiwan; 7 participants cleaned the environment for the affiliated preschool of the university; 3 participants served their home community and 2 participants ran a one-day primary school weekend camp with a student volunteer association.

\section{Data Sources}

Qualitative analysis was used in the study. For data collection, Krippendorff (1989) suggested written texts and verbal discussions be the sources of data for qualitative analysis. Hence, the participants' written reports and verbal presentations were used for analysis. The data included participants' speech reflections in the course, SL reports, and verbal presentations. It was classified based on the activity they were involved in. Then, each participant's speech reflection, SL report, and verbal presentation were put together and given a case code number. Table 1 shows the case codes. For example, case D01 was the participant listed on the first number for serving game activities for children with special needs.

Table 1. Case code and SL task

\begin{tabular}{|c|c|c|}
\hline Case Code & $\begin{array}{l}\text { The Number of } \\
\text { Participant }\end{array}$ & SL Task \\
\hline A & 38 & Holding game activities for children with special needs. \\
\hline B & 29 & Having community cleanup assigned by university student affairs practitioners. \\
\hline $\mathrm{C}$ & 11 & $\begin{array}{l}\text { Assisting an annual ceremony for special children/adults of an institution for Intellectual } \\
\text { and Developmental Disability. }\end{array}$ \\
\hline $\mathrm{D}$ & 9 & $\begin{array}{l}\text { Collecting receipts for the Taiwan receipt lottery on the street, known as a kind of } \\
\text { fundraising activity in Taiwan, for a foundation for elders. }\end{array}$ \\
\hline $\mathrm{E}$ & 7 & Cleaning the environment for the affiliated preschool of the university \\
\hline $\mathrm{F}$ & 3 & Serving their home community \\
\hline $\mathrm{G}$ & 2 & Assisting a one-day primary school weekend camp with a student volunteer association. \\
\hline
\end{tabular}

\section{Speech Reflections}

Participants wrote their reflections for speeches or classroom activities delivered by the course instructor and five experienced service volunteers during the volunteer basic and special training lessons. These reflections were classified based on the above case code and SL task.

\section{$S L$ reports}

At the end of their SL activities, each participant needed to answer three reflective questions for experiential learning based on Kolb's reflective model (1984). The questions were: 1 . What? What did I hear/see/contact from the service activity? 2. So what? What did I feel or think during the service activity? What did I learn and what did it mean to me? 3. Now what? How did the experiences in the SL activity change me? What can I do now?

\section{Verbal presentations}

By the end of the course, each participant needed to share their service activity experiences to all participants based on activity groups and their written reports. The course instructor asked questions 
after their presentations in order to verify their written reports and to obtain the missing parts of the written reports.

\section{Data Analysis}

For research analysis, all the data in the study were reviewed repeatedly in order to understand participants' moving images during the course and SL period. Next, the study tried to construct the meanings of the data through coding processes. For the first coding cycle, the initial categories were constructed from a single word or a full paragraph. Then, during the second coding cycle, the initial categories were changed, connected, categorized repeatedly through critical thinking until the researchers felt confident of codes to the data (Saldaña, 2013). The study tried to induct all categories into several common themes, but in vain. The only main theme among all the activities was "emotion process." For others, themes were not appeared until they were conducted based on the SL activity attributes. In other words, the SL activities were categorized into activities with interacting with children and ones without interacting with children. The SL activities with children were Case Code A, C, E, and G; the SL activities without children were Case Code B, D, F (see Table 1).

For research quality, the study used the following criteria advocated by Cuba and Lincoln: credibility, transferability, dependability, confirmability and authenticity (Lincoln \& Guba, 1985; Lincoln et al., 2011). The study provided negative/divergent case analyses and member checking by the second researcher for credibility, providing description of 99 participants' feedbacks for transferability, triangulation based on diverse data, and audition by the second researcher for dependability, data recheck and findings audition by both the first researcher and the second researcher for confirmability, and all participants' views through SL presentation by participants for authenticity.

\section{Limitation of the Study}

This study tried to explore the participants' experiences during the SL and was therefore constructed based on qualitative data (Creswell, 2012). Quantitative information was tried to be collected and counted in order to increase the reliability at first as Fife (2020) suggested. However, counting was not used in the study after considering pursuing unexpected findings from the participants and was not helpful to gain access to the perspectives of participants (Hannah \& Lautsch, 2011). In addition, the participant number of each SL activity was quite different and its quantitative data might not be meaningful due to the lack of reliability and validity for analysis. Hence, this study did not include quantitative information as some studies did to provide statistical data from the perspective of quantitative analysis.

\section{RESULTS}

\section{The Descriptions of the undergraduates to their SL}

According to the descriptions of the participants, the results showed ten categories were identified, listed based on alphabetical order in Table 2.

Table 2. Descriptive data for the categories

\begin{tabular}{|c|c|}
\hline Category & Illustrative Examples \\
\hline Communication & $\begin{array}{l}\text { "I learned how to interact with these adorable angles (special children) and learned how to execute } \\
\text { an activity (A16)." } \\
\text { "I learned a lot of communication skills from the service learning activity in order to speak } \\
\text { appropriately (D01)." }\end{array}$ \\
\hline Courage & $\begin{array}{l}\text { "I felt they (special children) were very brave. They were trying very hard to have a normal life } \\
\text { although they were different form us. So, I told myself I needed to work harder because the barriers } \\
\text { I faced were trivial compared to the barriers they faced (A 28)." }\end{array}$ \\
\hline Doubt & $\begin{array}{l}\text { "I felt it should be sincere to be a volunteer and it is meaningless to be a volunteer just for grades } \\
\text { (B06)." } \\
\text { "In my mind, it was a hard work to be a volunteer. That was why I was unwilling to do the service } \\
\text { learning activity at first (E04)." }\end{array}$ \\
\hline $\begin{array}{l}\text { Environment } \\
\text { protection }\end{array}$ & $\begin{array}{l}\text { "During the sweeping activity, I told myself repeatedly not to throw litters because I "now" learned } \\
\text { it was exhausting and hard to sweep streets (B13)." }\end{array}$ \\
\hline
\end{tabular}




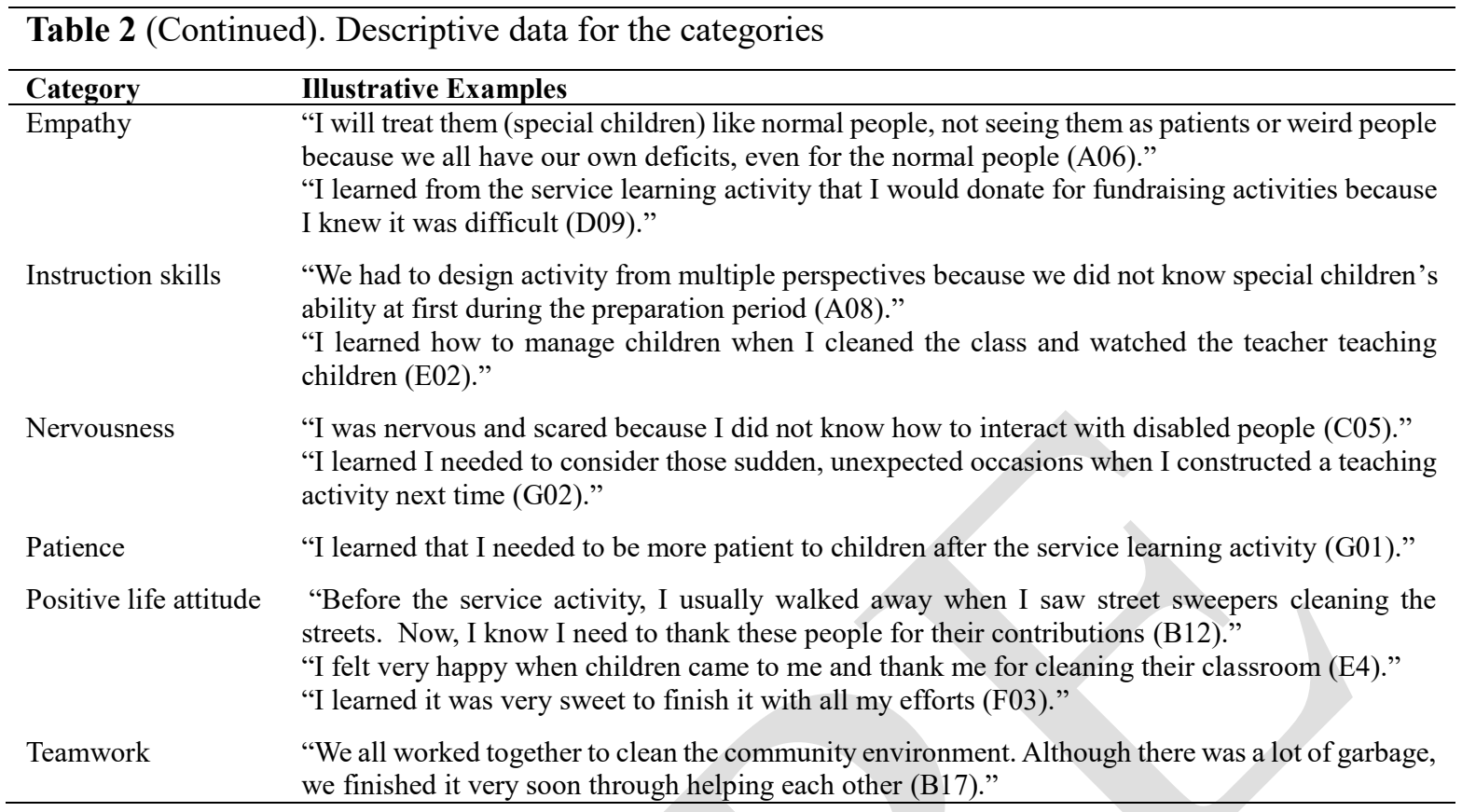

For further analyses based on the above ten categories, three coding themes were emerged as "emotion process", "professional skills", and "teacher traits." However, "environment protection," occurred only in the community cleanup (Case B), was not included in these themes. The connections among the categories and themes were revealed in Figure 1.

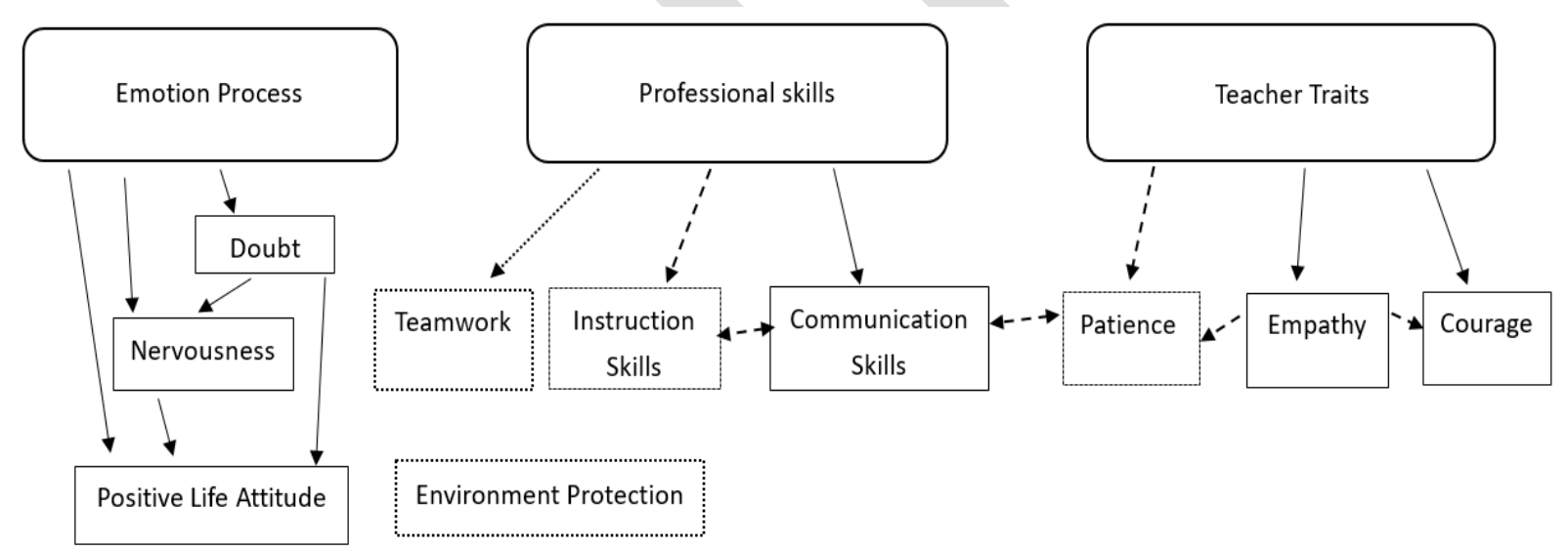

Note:

Figure 1. Coding hierarchy

1. "--" presents arrows, categories, or themes occurred in both SL activities with children and ones without children.

2. "- - -" presents arrows or categories occurred in SL activities without children.

3. "......" presents arrows or categories occurred in to SL activities without children.

4. " $\rightarrow$ " presents one way direction and " $\leftarrow \rightarrow$ " presents interactions between two categories.

\section{The general and different outcomes of SL}

Among the themes "emotion process," "professional skills," and "teacher traits," it was found categories in the theme of "emotion process" occurred in all SL activities. However, not all categories of "professional skills" and "teacher traits" appeared in all SL activities. The category "environment protection" only occurred in the activity of community cleanup (case code B).

\section{Emotion Process of the Participants}

The results showed participants experienced emotion process. Emotions were from their previous experience or cognition and from the interactions with people. In addition, the study showed there had 
been four different emotion processes since participants knew they were assigned to participant a SL activity. The four types of emotion process and their examples were described as follows:

\section{Type I Positive life attitude.}

The category "positive life attitude" was observed among all the activities. Most participants described they were happy, felt fulfilled, or thanked others for their contributions during or after their SL activity. "From their laugh and happiness, I felt they (special young children) were not different from us. I was happy I was good in health and had a good family" (A02). "I felt happy and helpful, and I would like to join more activities like this" (B16). "It made me feel I was lucky to have my healthy body from my parents and I wanted to thank my parents to let me do anything I liked to do" (C09). Also, it showed that participants who had volunteer experiences before the SL activities described they were glad to do SL. "I have been a volunteer since high school, and I have been glad to be a volunteer since then" (A02).

\section{Type II from doubt to positive life attitude.}

In the study, it also showed that few participants expressed their doubts or negative opinions concerning SL activities at the beginning of the course. However, they felt happy in the end.

In my mind, it was a hard work to be a volunteer. That was why I was unwilling to do the SL activity at first...... f felt happy when young kids came and said thanks to me after finishing the SL activity. (E04)

Type III from nervousness to positive life attitude.

Some participants felt nervous at the beginning of their SL activity, and were touched by the people they served.

I was very afraid that I would hurt these special children unconsciously because I did not know how to interact with them. I felt better after the teacher of the center taught us how to interact with special children......I was moved by their learning efforts and after hearing their laugh during the SL period...... After the SL activity, I would try myself to help them ......studying early intervention would be my goal. (A25)

Type from doubt to nervousness to positive life attitude.

It was found few participants criticized about the SL activities during the course, and then felt nervous at the beginning of their SL activity. However, they were affected by the served and therefore changed their thought.

Many people did SL just for assignments or grades, not voluntarily..... I felt fear when I first met special children/adults because I did not have any friends like them around me..... Their pureness and happiness infected me and my classmates..... 〔We〕 should not judge people by their appearance. ( $\mathrm{C} 01)$

From the perspective of early childhood teacher education, it seemed that the participants of different SL activities had different learning outcomes, especially in the themes of "professional skills" and "teacher traits" although all the activities shared the same emotion process.

\section{Professional skills}

"Communication Skills", "Instruction Skills" and "Teamwork" were the categories under the theme "Professional skills." As figured 1 showed, "Communication Skills" was presented both in SL activities with children and without children. "Instruction Skills" was the category only in SL activities with children, and "Teamwork" was the one happened in SL activities without children.

Concerning communication skills, participants of SL activities without children, especially in the fundraising activity, stressed the learning of communication manners. Also, it was interesting that communication means how to talk to different kinds of people. "I learned many communication skills, such as speaking in an appropriate manner, from the fundraising activity" (D01). "I learned how to communicate with people of different personality, especially facing their rejection" (D06). 
For SL activities with children, it focused on how to consider communication factors, how to communication with peers, with special children/adults, or in different languages. For example, in consideration of communication factors, a participant considered that "communication was the most important part during the SL activity. These factors, such as sound, intonation, body language, emotion, speaking or contact distance, and positive attitude affected communication" (A09). In communication with peers, a participant wrote "we had different opinions during the discussion because we needed to design the activity from different perspectives" (A08). In communication with special children/adults, it was written that "I learned how to interact with special children and their family" (A32) and "I learned how to listen to special children and responded to them appropriately" (A29). In communication in different languages, a participant said "I was a little bit nervous at first because I did not know which language (in Mandarin or Taiwanese) I should use to communicate with them" (A38).

For the category "Instruction skills," it was found only in the SL activities with children. A participant expressed "we needed to take factors, such as materials, activity procedures, space, cost, time, and difficulty level into consideration during the activity design period, although we had some quarrels and felt frustrated a little bit during the discussion" (A10). Another participant said, "I learned we needed skills to teach special children. For example, we needed to provide stuff which children with attention deficit hyperactivity disorder (ADHD) were interested in and then it would help them control their own emotion" (A19). "I would consider carefully how to deal with any contingencies when I designed the next learning game activity" (G02). In addition, there was an interaction between "Instruction Skills" and "Communication Skills". For example, "we needed to design a game activity from different perspectives because we did not understand the ability of special children, and therefore there were many different opinions during the discussion and communication" (A08).

The category "Teamwork" existed in the SL activities without children. A participant mentioned that "we worked together and helped each other happily to clean the community, and It was finished soon although there was a lot of garbage" (B17). Another said, "I was happy to work together with my partners to finish the SL activity to collet receipts for fundraising although we asked people to donate receipts with frustration and with exhaustion" (D6). However, it was interesting that participants in SL activities with children did not mention teamwork although they were grouped together to design activities and play with children in some activities. The reason might be they were frustrated in working together "on the condition of the limited design time, narrow activity space, and lack of resources" (A32).

\section{Teacher Traits}

The Categories "Empathy," "Courage," and "Patience" were occurred in the theme of "Teacher Traits." However, "Patience" happened only in SL activities with children.

"Empathy" was the category appearing in all SL activities. Participants understood and shared feelings of the served. "I was very happy to play with special children because they were very pure, so we needed to learn how to respect a person instead of hurting them" (A34). "I learned not to litter garbage. I did think it was exhausting to clean the streets. I was very proud of and thankful to street cleaners after the service activity" (B12). In addition, it was found empathy influenced participants' courage and patience in the SL activity with children. "Before, I was scared of the disabled and I easily gave up when I faced difficulties. However, I would insist more and have courage to face difficulties after seeing their efforts" (C03). "From the SL activity, I learned that these special children were just like us and we just needed to be with them with patience" (A32).

The category "Courage" happened in service activities both with children and without children. For activity with children, a participant described that "I told myself to work harder when I met some difficulties because I saw that special children lived very bravely and with great effort even though they lived in a difficult world" (A28). For activity without children, a participant said, "I learned from the SL activity that I needed to be courageous and to be creative when I met something unknown" (F01). 
The category "Patience" happened only in the activity with children. In addition, the category "Patience" was related to the category "Empathy." As a participant said, "I would be more patient to treat special children after I knew their diseases from the SL activity" (C10). Also, the category "Patience" was related to "Communication Skills". "I learned that special children would be understand what we said if we communicated with them patiently; in other words, we needed to tell them repeatedly and that would strengthen my patience" (A11).

\section{DISCUSSION and IMPLICATIONS}

\section{The factor of Emotion Process}

Our results showed that emotion process was an imperative factor that participants concerned among all the eight SL activities of the study. Participants experienced different kind of emotion processes during the SL. The factor of emotion was also found in some studies (Matheson and Petersen, 2020; Pratt \& Danyluk, 2017; Rodríguez-Nogueiraa et al., 2020). Matheson and Petersen (2020) stated their students felt a little bit fear for SL. Pratt and Danyluk (2017) expressed that their students felt fear or anxiety in the initial period, and then doubts and frustrations in the next period, and finally appreciation for SL experiences. Rodríguez-Nogueiraa et al. (2020) found their students significantly reduced their personal distress after the activity according to their quantitative analysis. Our study found students' emotions occurred from their cognition or previous experience and from the interactions with the served or community/institution partners during the SL process. Participants who had a good SL experience would be happy to have another one. On the contrary, participants who did the SL for the first time or contacted unfamiliar people/task might feel nervous or anxious about SL. Also, participants who were skeptical of SL and under unwell designed SL activity would felt frustrated. However, they would turn to be happy at the end of SL under the community/ institution partner's assistances or when the served gave them positive feedback. In other words, as Gardner (2021) stressed "how" SL does is less explored in research, rather than knowing "what" emotions are, our study argues, for course instructors, "how" students' emotions occur and "what" are students' emotion processes of SL are suggested to be considered while conducting a SL course since some research found students' academic satisfaction and achievement are connected to fewer bad emotional experiences and more good emotional experiences (Kleine, 2005; Lee \& Chei, 2020).

\section{Pre-service Teacher Education}

Research found SL promoted the positive learning outcomes of students, such as profession skills, communication skills, and collaboration. (Anderson et al., 2019; Leon et al., 2017; Lovat \& Clement, 2016; Popovich \& Brooks-Hurst, 2019; Pratt \& Danyluk, 2017; Edmond \& Driskill, 2019). So did the study find. This study found SL activities helped participants develop professional skills (i.e., "communication skills," "instruction skills," and "teamwork") and strengthen teacher traits (i.e., "patience," "empathy," and "courage."), which were important for pre-service teacher education (Hart \& Teeter, 2002; Kennedy, 2006).

Among the skills and traits, "communication skills," "empathy," and "courage" occurred both in activities with children and activities without children. However, this study also found that "patience" and "instruction skills" only appeared in activities with children, and "teamwork" was in activities without children. In other words, different SL activities would cause different and same learning outcomes. Therefore, course instructors should consider how to balance the student choice and the desired goals of course from SL activity, although student choice is an important factor for SL (Steinke et al., 2002).

Concerning professional skills, while examining the same learning outcome, for example, "communication skills," the study found the communication skills in different activities had subtly different contexts. For participants in SL activities without children, communication skills focused on communication manners on how to face different kinds of adults. For participants in activities with children, the communication skills meant not only how to communicate with different kinds of people (i.e., children, peers, and children's family), but also how to interact with children in appropriate 
teaching skills (i.e., sound, intonation, body language, and emotion) and with teacher traits (i.e., patience, empathy). In other words, participants were aware of or learned the importance of communication skills, such as enthusiastic manner, voice use, and gestures, for becoming effective teachers (Polk, 2006), or for being competent caregivers facilitating children's development (Akemoglu \& Meadan, 2018; Akemoglu et al, 2020). However, the study also found participants in the study did not mention or learn some other communication skills, such as the importance of clarity and positive verbal feedback (Polk, 2006). Hence, the study recommends that communication skills in SL for pre-service early childhood teacher's professional development may require further research.

For instruction skills, which only happened in activities with children, participants for the activity with special children stressed they learned how to design teaching activity, manage or interact with special young children, consider teaching resources, provide safety environment for special young children, or adapt teaching to special young children with patience; participants for the activity in preschool learned instruction skills mainly from observing preschool teachers' teaching activity and interacting with young children; participants for a one-day primary school weekend camp expressed they learned they needed to consider sudden, unexpected occasions while teaching and to teach children with patience. Hence, as a SL course instructor in early childhood pre-service teacher education, it seemed traits of SL activity influenced participants' professional development. Participants would learn instruction skills more and deeply when participants had more interactions with children. However, although the abundant instruction skills were learned by the participants, this study was lack of a systematic instruction skill inventory, as in Sornson study (2015), for students to evaluate their learning outcomes, and therefore a systematic instruction skill inventory is recommended.

When looking into the learning outcome "teamwork," it was interesting to find only participants in the activities without children mentioned teamwork, although participants in the activities with children were also grouped to work together. What caused the difference? What did it mean for a SL course or pre-service teacher education? The reason might be the participants' emotion process during their SL activity. As the results showed that participants in cleaning the community expressed they worked together happily to help each other, while, on the contrary, participants in the activity with children felt frustrated for poor peer communication and the limited teaching design time and resources for SL activity. Since teacher collaboration is an important factor for early children education (Jones et al., 2012), the study argues pre-service early childhood teacher educators shall consider how to encourage and increase good teamwork behaviors while designing a SL course.

For teacher traits, this study found "empathy," "courage," and "patience" were occurred in the theme of "teacher Traits." However, "Patience" happened only in SL activities with children. In addition, as figure 01showed, the category "Empathy" would influence participants to be courageous and patient, and there were interactions between "patience" and "communication skills" and between "communication skills" and "instruction skills." In other words, from the perspective of early childhood pre-service education, "empathy" might be the basic, important factor to increase pre-service teachers' teacher traits and instruction skills. In addition, from the participants' reflections, participants in SL with children gained courage mainly from observing special children's insistence in life; participants in the service activities without children gained courage from overcoming the tasks they were assigned. Hence, the study proved that the teacher traits"empathy," "courage," and "patience" found in the study were not only "natured," but also could be "nurtured" from SL activities.

\section{Conclusion}

This study explored how 99 undergraduate students of early child care and education felt and learned in seven SL activities from the perspective of pre-service teacher education. The seven SL activities could be categorized as SL activities with children or without children. The study found these students experienced emotion processes for their SL and how and what they experienced formed their professional skills and teacher traits. However, the study also found different SL activities would cause remarkably different learning outcomes. Hence, the study suggests course instructors should take the 
factor of "emotion process" into account and consider how to balance the student choice and the desired goals of course while constructing a courses with SL activities.

\section{Funding}

This research received no specific grant from any funding agency in the public, commercial, or not-forprofit sectors.

\section{Ethics and Conflict of Interest}

Approval from Institutional Review Board is waived from Southern Taiwan University of Science and Technology. As the authors of this study, we declare that we collected data in accordance with ethical rules during the research process and acted in accordance with all ethical rules. We also declare that there is no conflict between the authors.

\section{REFERENCES}

Akemoglu, Y., \& Meadan, H. (2018). Parent-implemented language and communication interventions for children with developmental delays and disabilities: A scoping review. Review Journal of Autism and Developmental Disorders, 5(3), 294-309

Akemoglu, Y., Meadan, H., \& Towson, J. (2020). Embedding naturalistic communication teaching strategies during shared interactive book reading for preschoolers with developmental delays: A Guide for Caregivers. Early Childhood Education Journal, 48(6), 759-766. https://doi.org/10.1007/s10643-020-01038-4

Anderson, K. L., Boyd, M., Ariemma Marin, K., \& McNamara, K. (2019). Reimagining service-learning: Deepening the impact of this high-impact practice. Journal of Experiential Education, 42(3), 229248. https://doi.org/10.1177/1053825919837735

Bach, T. (2016). Minding the gap: Teaching international climate change law through service learning. Vermont Journal of Environmental Law, 18(2), 173-193.

Chen, T., Snell, R. S., \& Wu, C. X. (2018). Comparing the effects of service-learning versus nonservice-learning project experiences on service leadership emergence and meaning schema transformation. Academy of Management Learning \& Education, 17(4), 474-495. https://doi.org/10.5465/amle.2016.0309

Cochran-Smith, M. (2003). Teaching quality matters. Journal of Teacher Education, 54(2), 95-98.

Creswell, J. W. (2012). Educational research: Planning, conducting, and evaluating quantitative and qualitative research (4 ed.). Pearson Education.

Deans, T. (2000). Writing partnerships: Service-learning in composition. NCTE.

Dent, L., Karp, T., \& Maloney, P. (2018). Self-efficacy development among students enrolled in an Engineering service-learning section. International Journal for Service Learning in Engineering, 13(2), 25-44. https://doi.org/10.24908/ijsle.v13i2.11483

Dewey, J. (1900). School and society ( $2^{\text {nd }}$ ed.). The University of Chicago Press.

Dewey, J. (1916). Democracy and education. The Free Press.

Dewey, J. (1933). How we think. Heath.

Dewey, J. (1938). Experience and education. Collier Books.

Dewey, J. (1946a). Problems of men. Greenwood Press.

Dewey, J. (1946b). The public and its problems (2 ${ }^{\text {nd }}$ ed.). Henry Holt and Company.

Edmond, T., \& Driskill, T. (2019). Gen Z: Exploring service learning projects in managerial accounting. Journal of Accounting and Finance, 19(4), 113-126. https://doi.org/10.33423/jaf.v19i4.2177

Erickson, J. A., \& Santmire, T. (2001). Psychological bases of effective service learning. In J. B. Anderson, K. J. Swick, \& J. Joost (Eds.), Service learning in teacher education: Enhancing the growth of new teachers, their students, and communities (pp. 19-38). AACTE.

Fertman, C. I., White, G. P., \& White, L. J. (1996). Service learning in the middle school: Building a culture of service. National Middle School Association.

Flecky, K. (2011). Foundations of service learning. In K. Flecky \& L. Gitlow (Eds.), Service-learning in occupational therapy education: Philosophy and practice (pp. 1-12). Jones Bartlett. 
Fife, W. (2020). Counting as a qualitative method: Grappling with the reliability issue in ethnographic research. http://dx.doi.org/10.1007/978-3-030-34803-8

Freire, P. (1973). Education for critical consciousness. Seabury Press.

Furness, R., \& Paulson, E. J. (2018). Ideas in practice: Service learning to motivate college writers. Journal of Developmental Education, 42(1), 16-21.

Gardner, P. (2021). Contemplative pedagogy: Fostering transformative learning in a critical service learning course. Journal of Experiential Education, 44(2), 152-166. https://doi.org/10.1177/1053825920952086

Giles, D., \& Eyler, J. (1994). The theoretical roots of service-learning in John Dewey: Toward a theory of service-learning. Michigan Journal of Community Service Learning, 1(1), 77-85.

Goldstein, L. S., \& Lake, V. E. (2000). Love, love and more love for children: Exploring pre-service Teachers' understanding of caring. Teaching and Teacher Education, 16(8), 861-872. https://doi.org/10.1016/S0742-051X(00)00031-7

Hannah, D. R., \& Lautsch, B. A. (2011). Counting in qualitative research: Why to conduct it, when to avoid it, and when to closet it. Journal of Management Inquiry, 20(1), 14-22. https://doi.org/10.1177/1056492610375988

Hart, P. D., \& Teeter, R. M. (2002). A national priority: Americans speak on teacher quality. Educational Testing Service.

Jacoby B. (1996). Service-learning in higher education: Concepts and practice. Jossey-Bass.

Jones, C., Ratcliff, N., Sheehan, H., \& Hunt, G. (2012). An analysis of teachers' and paraeducators' roles and responsibilities with implications for professional development. Early Childhood Education Journal, 40(1), 19-24. https://doi.org/10.1007/s10643-011-0487-4

Jones, I. (2017). Integrating Service Learning into Early Childhood Teacher Education: A Theoretical Perspective. In K.L. Heider (Ed.), Service Learning as Pedagogy in Early Childhood Education (pp. 1-14). Springer International Publishing.

Kaye, C. B. (2010). The complete guide to service learning. Free Spirit.

Kennedy, M. (2006). From teacher quality to quality teaching. Educational Leadership, 63(6), 14-19.

Kiely, R. (2005). Transformative international service learning. Academic Exchange Quarterly, 9(1), 275-281.

Kleine, M., Goetz, T., Pekrun R., \& Hall, N. (2005). The structure of students' emotions experienced during a mathematical achievement test. ZDM Mathematics Education, 37(3), 221-225.

Kolb, D. A. (1984). Experiential learning: Experience as the source of learning and development. Prentice Hall.

Krippendorff, K. (1989). Content analysis. In E. Barnouw, G. Gerbner, W. Schramm, T. L. Worth, \& L. Gross (Eds.), International encyclopedia of communication (Vol. 1, pp. 403-407). Oxford University Press.

Lee, J.-Y., \& Chei, M. J. (2020). Latent profile analysis of Korean undergraduates' academic emotions in e-learning environment. Educational Technology Research \& Development, 68(3), 1521-1546. https://doi.org/10.1007/s11423-01909715-x

Leon, K., Pinkert, L. A., \& Taylor, K. T. (2017). Developing accounts of instructor learning: Recognizing the impacts of servicelearning pedagogies on writing teachers. Composition Studies, 45(1), 39-58.

Liang, C. C., Seet, C., Jupri, N. F., Nasir, S. F. B. M., Masduki, N. A. B., Hambali, S. N. S. B., \& Sahri, N. A. B. M. (2019). Hearing the voices of the voiceless: Service-learning and its impact on aspects of social awareness amongst nursing and optometry students. Citizenship Teaching \& Learning, 14(2), 143-160. https://doi.org/10.1386/ctl_00002_1

Lincoln, Y. S. \& Guba, E. G. (1985). Naturalistic inquiry. Sage Publications.

Lincoln, Y. S., Lynham, S. A., \& Guba, E. G. (2011). Paradigmatic controversies, contra-dictions, and emerging confluences, revisited. In N.K. Denzin \& Y.S. Lincoln (eds), The Sage handbook of qualitative research (4th ed.; pp. 97-128). Sage Publications.

Lovat, T., \& Clement, N. (2016). Service learning as holistic values pedagogy. Journal of Experiential Education, 39(2), 115129. doi:10.1177/1053825916628548

Lowery, B. S., Unzueta, M. M., Knowles, E. D., \& Goff, P. A. (2006). Concern for the in-group and opposition to affirmative action. Journal of Personality and Social Psychology, 90(6), 961-974.

Matheson, B., \& Petersen, E. J. (2020). Engaging US students in culturally aware content creation and interactive technology design through service learning. IEEE Transactions on Professional Communication, 63(2), 188-200. https://doi.org/10.1109/TPC.2020.2982253

Myers, A. (2016). Building bridges to the world: Utilizing service learning during the senior year to develop participatory citizenship. American Secondary Education, 44(3), 4-12. 
Pascualy Cabo, D., Prada, J., \& Lowther Pereira, K. (2017). Effects of community service-learning on heritage language learners' attitudes toward their language and culture. Foreign Language Annals, 50(1), 71-83.

Patterson, G. C., \& Dunston, Y. L., \& Daniels, K. N. (2017). HBCUs to the rescue: Utilizing service-learning pedagogy to improve teacher preparation in early childhood education. In K.L. Heider(Ed.), Service Learning as pedagogy in early childhood education (pp. 81-92). Springer International Publishing.

Pertersen, N., \& Petker G. (2017). Teacher education students' struggles with group work in service learning. South African Journal of Childhood Education, 7(1), a479. https://doi.org/10.4102/sajce.v7i1.479

Polk, J. A. (2006). Traits of effective teachers. Arts Education Policy Review, 107(4), $23-29$. https://doi.org/10.3200/AEPR.107.4.23-29

Popovich, D., \& Brooks-Hurst, E. (2019). Assessing the perceived effectiveness of a marketing research service learning project: The MR-SL scale. Marketing Education Review, 29 (3), 164-181. https://doi.org/10.1080/10528008.2019.1621679

Pratt, Y. P., \& Danyluk, P. J. (2017). Learning what schooling left out: Making an indigenous case for critical service-learning and reconciliatory pedagogy within teacher education. Canadian Journal of Education, 40(1), 1-29.

Rodríguez-Nogueira, Ó., Moreno-Poyato, A. R., Álvarez-Álvarez, M. J., \& Pinto-Carral, A. (2020). Significant socio-emotional learning and improvement of empathy in physiotherapy students through service learning methodology: A mixed methods research. Nurse education today, 90, 104437. Advance online publication. https://doi.org/10.1016/i.nedt.2020.104437

Saldaña, J. (2013). The coding manual for qualitative researchers. Sage Publications.

Schön, D. A. (1987). Educating the reflective practitioner: Toward a new design for teaching and learning in the professions. Jossey-Bass.

Shor, I. (Ed.). (1987). Freire for the classroom: A sourcebook for liberatory teaching. Heinemann Press.

Sornson, B. (2015). The effects of using the essential skills inventory on teacher perception of high-quality classroom instruction. Preventing School Failure, 59(3), 161-167. https://doi.org/10.1080/1045988X.2014.886551

Steinke, P., Fitch, P., Johnson, C., \& Waldstein, F. (2002). An interdisciplinary study of service-learning predictors and outcomes among college students. In S. H. Billing \& A. Furco (Eds.), Advances in service-learning research, Vol 2: Service-learning research through a multidisciplinary lens, (pp. 73-102). Information Age.

Strait, J., \& Sauer, T. (2004). Constructing experiential learning for online courses: The birth of E-service. EDUCAUSE Quarterly, 27(1), 62-65.

Tokke, C. (2017). Academic service learning using affinity groups outside the box of business: A pedagogy model for community college business students. Community College Enterprise, 23(1), 26-42.

UNESCO (2006). Teachers and educational quality: monitoring global needs for 2015. Oxford University Press.

Volunteer Service Act, M.O.H.W. § 1-25 (2001 \& rev. 2020). https://law.moj.gov.tw/ENG/LawClass/LawAll.aspx?pcode=D0050131

Vogelgesang, L. J., \& Astin, A. N. (2000). Toward a theory of engagement: A cognitive mapping of service-learning experiences, Michigan Journal of Community Service Learning, 7(1), 14-25.

Vygotsky, L. S. (1978). Mind in society. Harvard University Press.

Weiler, K. (1991). Freire and a feminist pedagogy of difference. Harvard Educational Review, 61(4), 449-475.

Wilkinson, I. A. G., Doepker, G. M., \& Morbitt, D. (2012). Bringing service learning to scale in an undergraduate reading foundations course: A quasi-experimental study. Journal on Excellence in College Teaching, 23(2), 93-122. 